\title{
Cross-Cultural Analysis of the Use of Hedges in European and Pakistani English Newspaper: A Corpus-Based Study
}

\author{
Asmara Shafqat ${ }^{1}$, Rafique Ahmed Memon ${ }^{2} \&$ Huma Akhtar ${ }^{3}$ \\ ${ }^{1}$ Department of Humanities, NED University of Engineering \& Technology, Karachi, Pakistan \\ ${ }^{2}$ Institute of English Language and Literature, University of Sindh, Jamshoro, Sindh, Pakistan \\ ${ }^{3}$ Government Degree College for Women, Nazimabad, Karachi. Nawab Siddiqui road, Nazimabad, Karachi, \\ Pakistan \\ Correspondence: Huma Akhtar, Government Degree College for Women, Nazimabad, Karachi. Nawab Siddiqui \\ road, Nazimabad, Karachi, Pakistan. E-mail: humaakhtar123@hotmail.com
}

Received: May 20, $2019 \quad$ Accepted: June 11, $2019 \quad$ Online Published: August 26, 2019
doi:10.5539/ijel.v9n5p126
URL: https://doi.org/10.5539/ijel.v9n5p126

\begin{abstract}
Language, discourse and communication reveal social and cultural inclinations of human civilization (Van Dijk, 1997). Language behavior is exhibited through communication which is extracted from three main categories of language; "ideational, interpersonal and textual" (Halliday, 1978, 1985). Hedges are interpersonal metadiscourse markers (Hs), lexical devices that authors employ to arrange their discourse and communicate their standpoint about the substance for the reader. Cultural and linguistic background of the author may affect the employment of hedges in the discourse. The present study investigated the interpersonal metadiscourse marker-hedges- in the Culture section of European English Newspaper (CEEN) and Pakistani English Newspaper articles (CPEN) based on Hyland's classification (2004). The quantitative corpora-based study contained 32 articles from culture section of Pakistani English newspaper: Dawn News (DN) and 32 articles from culture section of European English Newspaper: BBC. The articles from each newspaper were extracted from online resources. Two corpora have equal representation of words, 40000 each. Data analysis was done using SPSS 22 to see the frequency of hedges used in the data. Moreover, an independent sample t-test was applied. It was found that there is a meaningful difference between the European and Pakistani English newspapers' usage of hedges. This research would help not only ELT practitioners to teach how hedges change the genre of discourse, but would also shed light on cultural discourse. It would depict how the same hedges are used in two different cultural discourses revealing distinct culture and identity.
\end{abstract}

Keywords: corpus, culture, discourse, hedges, ideational, interpersonal, metadiscourse, textual

\section{Introduction}

This study is comparative in nature with a primary focus on the employment of hedges, in Pakistani and European English news papers' culture section. Metadiscourse markers are the devices or tools that create and reflect the relationship between readers and authors. These markers are non-propositional tools employed in spoken and written language. Generally, research has categorized metadiscourse into two kinds of markers: interactional, which is sometimes called interpersonal and the other is textual. Textual metadiscourse is added in the text when it needs to have more coherence and cohesion. Interactional metadiscourse is the primary target of the present study that shows how writers communicate their attitude towards the discourse and assess the propositional content.

The progressive globalization and worldwide integration in the work has accelerated people's need to be engaged in international activities in the fields of religion, medicine, business, education and even military etc. People with different culture are becoming interdependent to each other so the intercultural communication is not new for them. The research in the area of intercultural communication has emerged and augmented the increasing interest among great number of researchers in this area so that it could guide people to learn universal understanding and prepare them with appropriate and successful communication skills in their communicative confrontations or encounters. Every language has a distinct rhetorical style and pattern of written texts. Therefore, means of persuasion are different across various types of genres. Hyland (2005) indicated that many editorials 
employ metadiscourse in multiple ways to influence. Numerous studies based on research articles (Dahl, 2014; Valero-Garces, 1996; Hyland, 1996a, 1996b, 2001), textbooks (Kuhi \& Behnam, 2010; Hyland, 1994, 1999, 2000), dissertations (Hyland \& Tse, 2004; Bunton, 1999; Hyland, 2004), casual conversations (Schiffrin, 1980) and company annual reports (Hyland, 1998b) have been conducted.

Despite the significance of this field in research, little research has been done both locally and internationally which might have studied the usage of hedges in the cultural sections of the English newspapers. This will add the knowledge in the local context. It will be significant not only educational sector but all the related fields where they can teach and learn how metadiscourse markers can be used to manipulate the attitude of the author and reader belonging to different cultural backgrounds. This will help all the disciplines involved in communication and pragmatics.

The cultural section of newspapers has not been examined where not only cultural identities, but also issues are different that lead authors to use metadiscourse cautiously. The present study has ascertained the difference in the usage of hedges in European and Pakistani English newspaper cultural articles. There are results of cross-cultural studies that claim that use of metadiscourse vary in different genres and contrastive rhetoric researches. Therefore, cross-linguistic studies on hedges in cultural articles expected to give interesting findings. This comparative, intercultural corpus-based study will highlight the importance of cultural articles in the English newspapers and will reveal the impact of the use of hedges in the style of writing of the authors from different cultures.

The term 'metadiscourse' is used to show how the ways authors exhibit their conceptions and attitudes or the ways their readers will understand them. In order to explain essays, to indicate intentions, to guide readers' responses, or organize texts as a whole and improve writing skills metadiscourse is used. It helps to guide the readers as how to comprehend and respond to the proposed material.

In Pakistan, not much research is available on hedges in the cultural section of the newspapers that may help teachers and students and any other who are involved in studying or teaching intercultural communication or pragmatics. Understanding hedges in cultural articles is an important aspect as it may help us comprehend the attitude, perception and preference of the writer towards the topic. The review of previous studies shows that metadiscourse has not been much analyzed crossed-linguistically in newspapers particularly in culture section. Abdollahzadeh (2007) studied metadiscourse in the newspapers' editorials. Mashhady, Fatollahi and Shahraki (2015) did contrastive analysis of metadiscourse in English and Persian editorials. Goudarzi and Farnia (2016) reviewed sports news in newspaper for interactional metadiscourse markers. Ahmed, Memon and Soomro (2017) investigated "interactional metadiscourse markers in British and Pakistani engineering articles".

This is the gap which is being explored in the present study. This study has aimed to probe usage of hedges, metadiscourse marker in cultural articles of European and Pakistani English newspapers revealing the cultural difference in the writing style.

\section{Literature Review}

"Metadiscourse" was first introduced by Hariss (1959) who elaborated the idea as a strategy to comprehend how language is used to represent attempt on writer's part to manipulate reader's view of the text (Hyland, 2005). For some later years, it was overlooked. During early 80 's the idea came up with a strong reaction with emphasis on the area of propositional language, and then subject of metadiscourse gained interest by many scholars (Crismore, 1983; Kopple, 1985; Williams, 1981).

Hyland (2010) acknowledged the notion of metadiscourse that replaced the previous idea which meant that the purpose of communication was to relate words to idea where language was taken primarily an expository and propositional mode of illustration. Hyland (2005) explained metadiscourse as an open and broad category that can be elaborated in multiple manners. Consequently, various taxonomies of metadiscourse used in text have been given by various researchers (Adel, 2006; Hyland \& Tse, 2004; Dafouze, 2003; Kopple, 1985; Hyland, 1998a, 1999). Many researchers consider that metadiscourse has two main categories: "textual and interpersonal". The stated classification of metadiscourse is emulated in many taxonomies under metadiscourse. However, Hyland and Tse (2004) rebuffed this twofold interpersonal and textual functions found in various metadiscourse researches (Hyland, 1998a, 1999; Crismore et al., 1993; Kopple, 1985).

Hyland (2005) suggested another typology of metadiscourse, summarized in Table 1. 
Table 1. An interpersonal model of Metadiscourse (Hyland, 2005, p. 49)

\begin{tabular}{lll}
\hline Category & Function & Examples \\
\hline $\begin{array}{ll}\text { Interactive } \\
\text { Transitions }\end{array}$ & Help to guide the reader through the text & Resources \\
Frame markers & Express relations between main clauses & In addition; but; thus; and \\
Endophoric markers & Refer to discourse acts, sequences and stages & Finally; to conclude; my purpose is \\
Evidentials & Refer to information in other parts of the text & Noted above; see figure; in section 2 \\
Code glosses & Refer to information from other texts & According to X; Z states; \\
Interactional & Elaborate propositional meaning & namely; e.g.; such as; in other words \\
Hedges & Involve the reader in the text & Resources \\
Boosters & Withhold commitment and open dialogue & Might; perhaps; possible; about \\
Attitude markers & Emphasize certainty and close dialogue & \\
Self-mentions & Express writer's attitude to proposition & Unfortunately; I agree; surprisingly \\
Engagement markers & Explicit reference to authors & I; we; my; me; our \\
\hline
\end{tabular}

Hyland (2005) categorized metadiscourse into two subgroups, one is interactive and the other is instructive. Interactive metadiscourse comprises of propositional content that directed towards a targeted audience which is possibly perceived as convincing and coherent. On contrary, interactional characteristics involve audiences and build prospects for them to add to the discourse by notifying them about the writer's standpoint towards readers and propositional content.

In this study hedges have been studied. Hedges represent the author's unwillingness to the proposition as a proven idea (Hyland \& Tse, 2004). Some tools, for example: "perhaps", "might" and "possible" are used to refuse the absolute commitment or dedication to propositional information. They allow prejudice as they tend to present information as an opinion rather than the fact. It is about author's conceivable interpretation rather than particular knowledge.

Many researchers have given various taxonomies of hedges (Koppel, 2002; Salager-Meyer, 1994; Hyland, 1998a, 2000; Crompton, 1997). It is notable that the taxonomies presented by Hyland (1998a) and Salager-Myer (1994) are extensively employed in many researches of hedging devices (Tran \& Duong, 2013; Bonyadi et al., 2012; Rezanejad et al., 2015) because of their adequacy and impact. Salager-Meyer (1994) categorized hedges on the basis of their functions that include: 'frequency, shields, time, and approximators of degree, emotionally charged intensifiers; quantity, expressions of writer's personal doubt; compound hedges and author's direct involvement'.

Hyland (1996) bi-furcated hedges into two sub-categories: 'reader-oriented' and 'content oriented'. The 'content-oriented' or 'writer oriented' hedges help the authors to exhibit claims with accuracy related to the real world situation and the extent of authenticity of the author insert in the statement and in preserving truth of a statement to stop the harm that might be a consequence of 'bald propositions' (Hyland, 1996).

The 'reader-oriented' group offer acknowledgment to the reader and shun improper impudence (Hyland, 1996). Hyland (1998a) included the modal auxiliaries in the taxonomies of hedges, epistemic adjectives and adverbs and epistemic lexical verbs. For example: should, may, could, would, might, perhaps, possible, about, possibly, apparent, likely, unlikely, seem, indicate, assume, suggest and propose etc.

Scientific arguments and assertions along with lexical items can be alleviated by using hedges that limit the information of theory, method or model or by limiting the experimental issues and other various acts can be achieved without any violation (Hyland, 1998a).

A writer who expresses meaning and sense must recognize the social impact and related repercussion that it might have on readers or audience who deduce the meaning, and these readers are the ultimate audience for the purpose of communication. Hyland (2005) has stated that the tool to attain this purpose is metadiscourse that grant the writer to achieve it. This engages authors and the readers in bilateral acts of understanding, involvement and comprehension. Writers practice metadiscourse to persuade the audience and to present adequate professional persona. Thus, convincing and persuasive speech or texts can be viewed as the main objects for metadiscourse examinations.

Many writers acknowledge the fact that newspapers also design and create a genre (Shams, 2005; Fowler, 1991; Bell, 1991; Bhatia, 1993). Newspaper genre is considered as a 'socio-cultural movement or activity' in which the author compiles and reviews important things to the audience (Abdollahzadeh, 2007). This strenuous practice urges the author to be persuasive and be cautious to write in a very safe tone so that it may sustain, or oppose a standpoint, or create awareness towards a grave matter. For this, they use metadiscourse to arrange and 
systematize the text and put across their credibility, personality and regard for the audience (Abdollahzadeh, 2007).

Furthermore, as stated by Moreno (1997, p. 5) "writing is a cultural object". Contrastive language, writing and rhetoric are cultural phenomena (Kaplan, 1996). Every language has specific abstract and rhetorical practice (Connor, 1996). Consequently, metadiscourse is used differently at cross cultural level in various genres. Ansary and Babaii (2009) believed that editorials of newspapers are specifically significant genres to examine at cross-cultural level as they are 'persuasive, open' and most likely represent ideological inclination and culture.

Culture influences the writer's perspectives and perception the way they organize their ideas and write. Language and culture are inseparable; they are entrenched in the language, and suggest ways of involving readers in content. Thus, they influence use of language and learning, beliefs, conversations and usage of metadiscourse markers (Hyland, 2005). In English cultural writing, the author intends to direct the readers or audience towards the writing or a piece of text for powerful communication between them.

On the other hand, according to Hyland (2005), in cultures like Japan comprehension is left to readers and content is implicit and not explicit. Generally, first language (L1) and second language (L2) authors inclined to prefer distinct approaches pattern and ways to organize and manage their ideas and viewpoints and tend to involve audience in their texts. Different cultures have their own unique values, norms, and language and specific means of communication. Consequently, that makes coherent and well-organized text is different across all cultures.

Navratilove (2016) defended the idea and examined the use of hedges in cross culturally written research studies by Czech linguists and Anglophone that resulted in low use of boosters and hedges by Czech linguists. Navratilove (2016) stated that the authors' ways of using hedging devices are influenced not only by their cultural, social background but also by their epistemological association with literacy practices, genre and disciplinary traditions (Jaliflifar, 2011; Orta \& Giner, 2008; Rezanejad, Lari, \& Mosalli, 2015). Lores-Sanz's study (2010) focused English and Spanish research articles corpora, which represented the high frequency use of hedges in English corpora as compared to Spanish corpora. Marrandi (2002) also found that the non-native Persian writers employed more metadiscourse markers to than English speaking writers. The study of Abdollahzadeh (2003) unfolded a noteworthy difference between native and non-native writers' preference of interpersonal metadiscourse. Dafouz-Milne's (2003) study found that interactional metadiscourse markers in sports articles were used more by Spanish authors than by English writers. British writers used more interpersonal markers. Rahimpour's (2006) analysis of research articles by English and Persian authors found that (2006) English authors used great number of textual discourse markers. Overall, interpersonal metadiscourse was used less than other metadiscourse. Abdollahzadeh (2007) contended in his study of newspaper editorials that English editorials employed more hedges than Persian. English editorial authors are considered more polite due to this their editorials were high number of hedges. Faghih and Rahimpour (2009) in their findings established that the native English speaker employed more interactional discourse markers. Iranians used more code glosses and frame markers. Hashemi and Golparvar (2012) explored that interpersonal and textual metadiscourse markers were higher in Persian news reports. The findings of Yazdani, sharifi, and Elyassi (2014) showed that English journalists employed more personal markers than Iranian; instead Iranian used passive structures with third person. Noorian and Biria (2010) examined metadiscourse markers in 'persuasive discourse' and a noteworthy difference was found between both corpora in usage of metadiscourse, revealing the reasons of difference that there may be genre-driver conventions, culture-driven preferences, and Iranian non-native English authors' extent of expertise in second or foreign language linked with choosing the interpersonal metadiscourse by the news reporters or columnists.

Ahmed, Memon and Soomro (2017) investigated instructional metadiscourse markers in British and Pakistani engineering research articles based on cross cultural study. The findings of the research showed that interactional markers were more used by British authors than Pakistani authors. The only metadiscourse marker was booster which was used by Pakistani writers slightly more than British authors.

This research investigated how culture and inter-culturality is composed in culture section of European English newspaper and Pakistani English newspapers. Interculturality is built as a comprehensive phrase masking an overabundance of expressions refereeing to cultural diversity, multicultursim; variations or differences in cultural, hybridity etc. (Dervin \& Risager's, 2015). Research in intercultural communication has growingly employed a discourse-based method or approaches, to search how text and words construct meanings (Scollon, Scollon, \& Jones, 2012). The aim of this study is to present the extent of interculturality and inflections of the culture as they can be investigated employing the corpus method in combination of discourse methods (Handford 
2014, 2016; Baker, 2006; Sinclair, 2004; McEnery \& Hardie, 2012).

The objective of this study is to add in the research area on the use of hedges cultural articles of newspapers and to claim that the vital aim of hedging devices is to mitigate the writer's attitude towards the propositions and statements.

\section{Method}

\subsection{Corpora}

The data for the study were taken from DAWN a renowned Pakistani English newspaper (CPEN). The culture section of the newspaper was the focus of the research; therefore, the required number of articles from the culture section was downloaded. Another part of the data was taken from the BBC which is internationally renowned English newspaper (CEEN). The same culture section of this newspaper was taken into account and articles were downloaded from it. All the data were taken from the websites of both the newspapers.

Almost 32 articles from each newspaper were downloaded making the corpus of 40000 each. The corpora were made of around 80000 words equal representation of both the newspapers. The authors of articles from the DAWN newspaper are Non- native speakers of English, whereas the writers of the BBC are native speaker of English.

\subsection{Procedure}

Various modals or taxonomies have been given for the categorization of hedges, but this study was based on the use of the hedges, the interpersonal metadiscourse markers based on the model of Hyland (2005). From the downloaded corpora, the hedges and sub-categories of hedges were recognized and identified. The following hedging devices were divided into four categories that were investigated in the study:

1) Lexical verbs: seem, suggest, believe, claim, doubt, tend, indicate, assume, estimate, suspect ...

2) Epistemic adverbs: often, perhaps, almost, quite, possibly, mostly, apparently, sometimes, usually, probably, frequently, generally, largely, mainly, seemingly, approximately, essentially, somewhat, presumably ...

3) Epistemic adjectives: little, possible, likely, unlikely, apparent ...

4) Modal verbs: could/n't, may, might, maybe, would/n't ...

Ant.Conc software was used to examine if any difference existed in two Pakistani and European corpora in terms of hedges. Concordance and cluster token tools were used to get the number and frequencies of the terms under investigation. Further, it was important to analyze and scan the terms because this software can work at the lexical and not at the pragmatics or semantic level. Each occurrence of the word was checked to make sure the word was used as a hedge. The corpora were compiled and interpreted to achieve research objectives.

\subsection{Variables}

There is one categorical variable in the present study with two sub groups which is Corpora of culture articles of English newspapers (CCAEN). The sub categorical variables are corpora of Pakistani English newspaper (CCAPEN) and corpora of culture articles of European English newspapers (CCAEEN).

The continuous variables of the present study are: modal verbs, lexical verbs, epistemic adjectives, and epistemic adverbs.

To investigate the difference between the two corpora independent sample $t$ test was applied based on these variables.

\subsection{Research Questions}

The research questions of the present study were:

1) Do the corpora comprise of culture articles of Pakistani English newspapers and European English newspapers show any difference in the overall frequency of hedges?

2) Is there any difference between the two corpora comprised of Pakistani English newspaper culture articles and European English newspaper culture articles in terms of the frequencies of different types of hedges?

\subsection{Hypotheses}

The following hypotheses developed out of the research questions:

- $\quad \mathrm{H}_{1}$ : Corpus of Pakistani English newspaper culture articles uses more lexical verbs than the corpus of European English newspaper culture articles. 
- H1: Corpus of Pakistani English newspaper culture articles does not use more lexical verbs than the corpus of European English newspaper culture articles.

- $\mathrm{HO}_{2}$ : Corpus of Pakistani English newspaper culture articles uses more epistemic adverbs than the corpus of European English newspaper culture articles.

- H1: Corpus of Pakistani English newspaper culture articles does not use more epistemic adverbs than the corpus of European English newspaper culture articles.

- $\quad \mathrm{HO}_{3}$ : Corpus of Pakistani English newspaper culture articles uses more epistemic adjectives than the corpus of European English newspaper culture articles.

- H1: Corpus of Pakistani English newspaper culture articles does not use more epistemic adjectives than the corpus of European English newspaper culture articles

- $\mathrm{HO}_{4}$ : Corpus of Pakistani English newspaper culture articles uses more modal verbs than the corpus of European English newspaper culture articles.

- H1: Corpus of Pakistani English newspaper culture articles does not use more modal verbs than the corpus of European English newspaper culture articles.

\section{Results}

After analysis through the software AntConc, it was found out that there were total 80000 words in the two corpora which is called token in corpus linguistics. The corpora were composed of 40000 each corpus contained culture articles of Pakistani and European English Newspapers.

Table 2. Corpora demographics

\begin{tabular}{ll}
\hline Total word Token & 80000 \\
Total Word Types & 11073 \\
Total number of Hedges & 38 \\
\hline
\end{tabular}

The first research question focused on finding difference in the occurance of the hedging devices. The number of hedges were summarised into five groups on the basis of Hyland's (2005) model. Total occurance of hedges were identified and were put into the groups. According to the Table 3, The first group of hedge type lexical verbs in CCAPEN showed the frequency of $5.99 \%$ which is less than the corpus of CCAEEN which is $7.82 \%$; the frequency of second hedge type epistemic adverbs in CCAEEN is $25.60 \%$ more than CCAPEN that showed the frequency $20.22 \%$. The third group of hedge type epistemic adjective in CCAPEN showed more occurances with $33.86 \%$ more than the frequency of the same hedge type in CCAEEN which was $31.91 \%$. CCAPEN reperesented more percentage of modal verbs which was $39.90 \%$ than the CCAEEN with $34.68 \%$.

After analyses, the result concluded that the corpus of culture articles of European English newspaper showed more number of lexical verbs and epistemic adverbs. Whereas the corpus of culutre articles of Pakistani English newspaper used more epistemic adjectives and modal verbs.

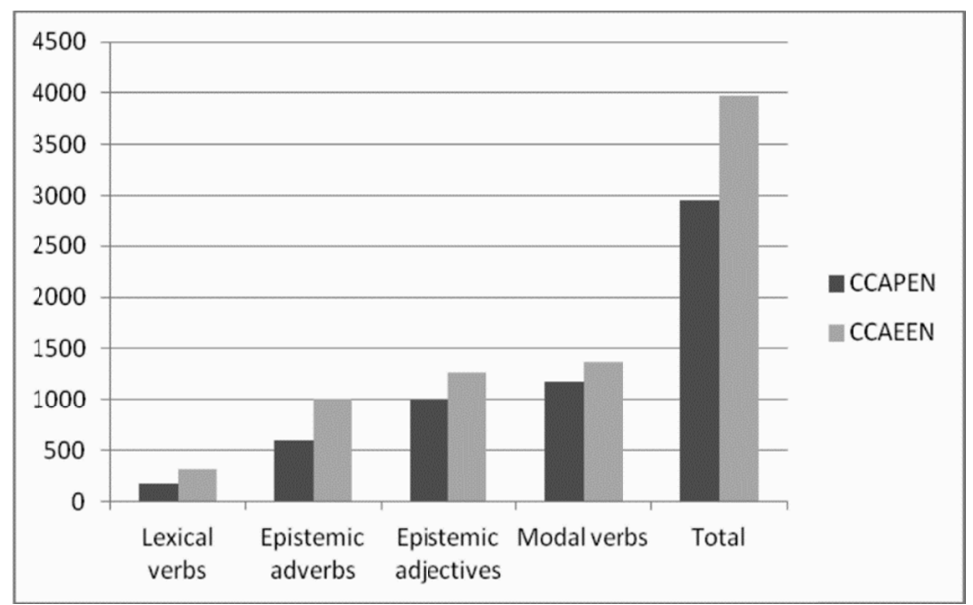

Figure 1. Hedging devices used between the two corpora 
Table 3. Hedge types and their frequencies

\begin{tabular}{llllll}
\hline Hedge Type & CCAPEN & f & CCAEEN & f & Total \\
\hline Lexical verbs & 177 & $5.99 \%$ & 310 & $7.82 \%$ & 487 \\
Epistemic adverbs & 597 & $20.22 \%$ & 1016 & $25.60 \%$ & 1613 \\
Epistemic adjectives & 1000 & $33.86 \%$ & 1266 & $31.91 \%$ & 2266 \\
Modal verbs & 1178 & $39.90 \%$ & 1376 & $34.68 \%$ & 2554 \\
Total & 2952 & $42.65 \%$ & 3968 & $57.34 \%$ & 6920 \\
\hline
\end{tabular}

For second research question, the hypotheses were developed and investigated. The independent sample t-test was applied as the researcher had two independent samples of the data and researcher wanted to make the comparison of the two corpora; one was culture articles of Pakistani English newspaper and the other was the corpus of European English newspaper. There were categorical variables with two sub groups and lexical verbs, a continuous variable.

$\mathrm{HO}_{1}$ : Corpus of Pakistani English newspaper culture articles uses more lexical verbs than the corpus of European English newspaper culture articles.

An independent sample t-Test was conducted to see the difference between the two corpora in terms of lexical verbs. There was a prominent difference in the frequency of lexical verbs of CCAPEN $(\mathrm{M}=5.5, \mathrm{SD}=2.0)$ and of CCAEEN $(\mathrm{M}=9.7, \mathrm{SD}=1.4) ; \mathrm{t}(62)=-9.5, \mathrm{p}=.000$. The results according to Table 5, suggest that there is significant difference between the two corpora in terms of lexical verbs. Culture articles of European English newspaper use more lexical verbs than culture articles of Pakistani English newspaper, therefore, the null hypothesis has been rejected because $(\mathrm{p}<.05)$.

Table 4. Group statistics

\begin{tabular}{llllll}
\hline & Corpora of culture articles of English newspapers & $\mathrm{N}$ & Mean & Std. Deviation & Std. Error Mean \\
\hline Lexical Verbs & CCAPEN & 32 & 5.53 & 2.032 & .359 \\
& CCAEEN & 32 & 9.69 & 1.424 & .252 \\
\hline
\end{tabular}

Table 5. Independent samples t-Test result for lexical verbs in two corpora

\begin{tabular}{lllllll}
\hline & & \multicolumn{4}{l}{ Levene's Test for Equality of Variances } & \multicolumn{2}{l}{ t-test for Equality of Means } \\
\cline { 3 - 6 } & & F & Sig. & t & df & Sig. (2-tailed) \\
\hline Lexical Verbs & Equal variances assumed & 4.093 & .047 & -9.476 & 62 & .000 \\
\hline
\end{tabular}

$\mathrm{HO}_{2}$ : Corpus of Pakistani English newspaper culture articles uses more epistemic adverbs than the corpus of European English newspaper culture articles.

An independent sample t-Test was conducted to see the difference between the two corpora in terms of epistemic adverbs. A significant difference in the frequency of lexical verbs of CCAPEN ( $\mathrm{M}=18.7, \mathrm{SD}=4.9)$ and of CCAEEN ( $\mathrm{M}=31.8, \mathrm{SD}=2.5)$; $\mathrm{t}(62)=-13.5, \mathrm{p}=.000$ was found. The results, according to Table 7 , suggest that the two corpora have difference in the occurrence of epistemic adverbs. Culture articles of European English newspaper use more epistemic adverbs than culture articles of Pakistani English newspaper, therefore, the null hypothesis has been rejected because $(\mathrm{p}<.05)$.

Table 6. Group statistics

\begin{tabular}{llllll}
\hline Corpora of culture articles of English newspapers & $\mathrm{N}$ & Mean & Std. Deviation & Std. Error Mean \\
\hline \multirow{2}{*}{ Epistemic Adverbs } & CCAPEN & 32 & 18.66 & 4.896 & .866 \\
& CCAEEN & 32 & 31.75 & 2.514 & .445 \\
\hline
\end{tabular}

Table 7. Independent samples t-Test result for epistemic adverbs in two corpora Independent Samples Test

\begin{tabular}{lllllll}
\hline & \multicolumn{4}{l}{ Levene's Test for Equality of Variances } & t-test for Equality of Means \\
\cline { 2 - 7 } & F & Sig. & t & df & Sig. (2-tailed) \\
\hline Epistemic Adverbs & Equal variances assumed & 17.490 & .000 & -13.457 & 62 & .000 \\
& Equal variances not assumed & & & -13.457 & 46.287 & .000 \\
\hline
\end{tabular}


$\mathrm{HO}_{3}$ : Corpus of Pakistani English newspaper culture articles uses more epistemic adjectives than the corpus of European English newspaper culture articles.

An independent sample t-Test was conducted to see the difference between the two corpora in terms of epistemic adjectives. A significant difference in the frequency of epistemic adjectives of CCAPEN $(\mathrm{M}=31.3, \mathrm{SD}=1.6)$ and of CCAEEN $(\mathrm{M}=39.6, \mathrm{SD}=1.8) ; \mathrm{t}(61)=-19.8, \mathrm{p}=.000$ was found. The results according to Table 9, suggest that there is significant difference between the two corpora in terms of epistemic adjectives. Culture articles of European English newspaper use more epistemic adjectives than culture articles of Pakistani English newspaper, therefore, the null hypothesis has been rejected because $(\mathrm{p}<.05)$

Table 8. Group statistics

\begin{tabular}{llllll}
\hline & Corpus of culture articles of English newspapers & N & Mean & Std. Deviation & Std. Error Mean \\
\hline Epistemic Adjectives & CCAPEN & 32 & 31.25 & 1.566 & .277 \\
& CCAEEN & 32 & 39.56 & 1.795 & .317 \\
\hline
\end{tabular}

Table 9. Independent samples t-Test result for epistemic adjectives in two corpora Independent Samples Test

\begin{tabular}{cllllll}
\hline & \multicolumn{4}{l}{ Levene's Test for Equality of Variances } & t-test for Equality of Means \\
\cline { 2 - 7 } & & F & Sig. & t & df & Sig. (2-tailed) \\
\hline Epistemic Adverbs & Equal variances assumed & 2.225 & .141 & -19.742 & 62 & .000 \\
& Equal variances not assumed & & & -19.742 & 60.878 & .000 \\
\hline
\end{tabular}

$\mathrm{HO}_{4}$ : Corpus of Pakistani English newspaper culture articles uses more modal verbs than the corpus of European English newspaper culture articles.

An independent sample t-Test was conducted to see the difference between the two corpora in terms of modal verbs. There was a significant difference in the frequency of modal verbs of CCAPEN $(\mathrm{M}=37, \mathrm{SD}=1.6)$ and of CCAEEN $(M=43, S D=1.8) ; t(62)=-14.82, p=.000$. The results, according to Table 11 , suggest that there is a significant difference between the two corpora in terms of modal verbs. Culture articles of European English newspaper use more modal verbs than culture articles of Pakistani English newspaper, therefore, the null hypothesis has been rejected because $(\mathrm{p}<.05)$.

Table 10. Group Statistics

\begin{tabular}{llllll}
\hline & Corpus of culture articles of English newspapers & $\mathrm{N}$ & Mean & Std. Deviation & Std. Error Mean \\
\hline \multirow{2}{*}{ Modal Verbs } & CCAPEN & 32 & 36.81 & 1.575 & .278 \\
& CCAEEN & 32 & 43.00 & 1.760 & .311 \\
\hline
\end{tabular}

Table 11. Independent Samples t-Test result for modal verbs in two corpora Independent Samples Test

\begin{tabular}{lllllll}
\hline & & \multicolumn{2}{l}{ Levene's Test for Equality of Variances } & t-test for Equality of Means & \\
\cline { 3 - 7 } & & $\mathrm{F}$ & $\mathrm{Sig}$ & $\mathrm{t}$ & $\mathrm{df}$ & Sig. (2-tailed) \\
\hline \multirow{2}{*}{ Modal Verbs } & Equal variances assumed & 1.353 & .249 & -14.822 & 62 & .000 \\
& Equal variances not assumed & & & -14.822 & 61.250 & .000 \\
\hline
\end{tabular}

\section{Discussion and Conclusion}

The results of the present research proposed the presence of categorized interpersonal metadiscourse; hedges are employed in culture articles of English European and Pakistani newspapers. The analysis of the first research question showed that there is a variation and differences in the occurrence of the categorized hedges between the two corpora CCAPEN and CCAEEN. It is concluded that CCAPEN used more epistemic adjectives $(33.86 \%)$ and modal verbs $(39.90 \%)$ than the CCAEEN. On the other hand, CCAEEN used more lexical verbs $(7.82 \%)$, epistemic adverbs (25.60).

The investigation of the second research question demonstrated significant and prominent difference between the hedges between the two corpora, CCAPEN and CCAEEN, in terms of modal verbs, lexical verbs, epistemic adjectives, and epistemic adverbs. The entire null hypotheses have been rejected.

If we look at the conclusions, the difference may be culture-related or other pragmatic issues. As many studies 
stress on the use of hedges as they are desired by the speakers of a certain language. The results did not match with Hinkel's (1997) who found that native and non-native writers of English did not differ in their usage of hedges significantly. Modal verbs were the most used hedge type in culture articles in both the corpora; they can be taken as the primary feature, or element in the corpora of culture articles of English newspaper irrespective of the difference of the cultures. The study by Mauranen (1997) suggested that writers who have low proficiency in using of hedge devices use fewer hedges than the proficient one. It does not guarantee that all native writers of English use more hedges for example, in this study some categories of hedges are used more by Pakistani English writers of culture articles and some hedge types are used more by European English writers of culture articles. There are numerous factors that may influence the writer to use hedge devices that may reflect his or her opinions, beliefs, perspectives, considerations, etc. that are bound to various elements of culturally motivated society or any other institutional aims.

Hedges, a functional tool of a language, create a relationship or association between cultures and texts to describe the symbolic context by presenting some of the beliefs and understanding to the target audience. The patterns in differences of the use of hedges could show a significant means of distinct discourse communities and the ways and approaches authors recognize the inferences they want their audience to assume. Hedges may be used to exploit the beliefs, preferences and opinions of the culture, society and other social groups. The achieved results might be useful for ELT practitioners not only to those who are involved in teaching writing but also teaching reading, and specifically writing for the specific purpose for English writing learners.

The findings are in contrast with the results of the Carlson (1988) and Hinkel (1997) that showed that non-native and native writers of English did not differ significantly in terms of the types of hedges. This study established that there is a significant difference between European and Pakistani writers in terms of their use of hedges and their types in culture articles.

One cannot completely say that only native writers as compared to the non-native ones use more hedges than or vice versa. In this study, it is revealed that there may be differences in hedges types and different frequencies in the two corpora.

Since metadiscourse is largely related to the pragmatics and discourse, therefore, people who are engaged (the practitioners and professional users of metadiscourse) must concentrate in this area of language to subdue the difficulty of using hedges (Crismore, Markkanen, \& Steffensen, 1993). The present study can provide guidance to foreign or second language teachers and learners.

\section{References}

Abdollahzadeh, E. (2007, July). Writer's presence in Persian and English newspaper editorials. In International Conference on Systemic Functional Linguistics in Odense, Denmark.

Ädel, A. (2006). Metadiscourse in L1 and L2 English. Amsterdam: John Benjamins. https://doi.org/10.1075/scl.24

Ahmed, M., Memon, S., \& Soomro, A. F. (2017). An Investigation of the Use of Interactional Metadiscourse Markers: A Cross-Cultural Study of British and Pakistani Engineering Research Articles. ARIEL-An International Research Journal of English Language and Literature, 27.

Ansary, H., \& Babaii, E. (2009). A cross-cultural analysis of English newspaper editorials: A systemic-functional view of text for contrastive rhetoric research. RELC Journal, 40(2), 211-249. https://doi.org/10.1177/0033688209105867

Baker, P. (2006). Using corpora in discourse analysis. A\&C Black.

Bonyadi, A., Gholami, J., \& Nasiri, S. (2012). A contrastive study of hedging in environmental sciences research articles. Journal of Language Teaching and Research, 3(6), 1186. https://doi.org/10.4304/j1tr.3.6.1186-1193

Crismore, A. (1983). Metadiscourse: What it is and how it is used in school and non-school social science texts. Center for the Study of Reading Technical Report, no. 273.

Crompton, P. (1997). Hedging in academic writing: Some theoretical problems. English for Specific Purposes, 16(4), 271-287. https://doi.org/10.1016/S0889-4906(97)00007-0

Dafouz-Milne, E. (2003). Metadiscourse revisited: a contrastive study of persuasive writing in professional discourse. Estud. Ingl. Univ. Complut, 11, 29-52.

Dafouz-Milne, E. (2008). The pragmatic role of textual and interpersonal metadiscourse markers in the construction and attainment of persuasion: A cross-linguistic study of newspaper discourse. Journal of 
pragmatics, 40(1), 95-113. https://doi.org/10.1016/j.pragma.2007.10.003

Dahl, T. (2004). Textual metadiscourse in research articles: a marker of national culture or of academic discipline? Journal of Pragmatics, 36, 1807-1825. https://doi.org/10.1016/j.pragma.2004.05.004

Dontcheva-Navrátilová, O. (2013). Authorial presence in academic discourse: functions of author-reference pronouns. Linguistica Pragensia, 23(1), 9-30.

Dontcheva-Navrátilová, O. (2018). Persuasion in academic discourse. Persuasion in Public Discourse: Cognitive and Functional Perspectives, 79, 227. https://doi.org/10.1075/dapsac.79.11don

Faghih, E. \& Rahimpour, S. (2009). Contrastive rhetoric of English and Persian written texts: Metadiscourse in applied linguistics research articles. Rice Working Papers in Linguistics, 1, 92-107.

Falahati, R. (2004). A contrastive study of hedging in English and Farsi academic discourse. An MA thesis submitted to the Department of Linguistics, University of Victoria.

Fowler, R. (1991). Language in the news: Discourse and ideology in the press. London: Routledge.

Goudarzi, Z., \& Farnia, M. (2016). Interactional Metadiscourse Markers in Sports News in Newspapers: A Cross-cultural study of American and Iranian Columnists.

Halliday, M. (1973). Explorations in the functions of language. London: Arnold.

Handford, M. (2014). Cultural identities in international, interorganisational meetings: a corpus-informed discourse analysis of indexical we. Language and Intercultural Communication, 14(1), 41-58. https://doi.org/10.1080/14708477.2013.866123

Harris, Z. (1959). The transformational model of language structure. Anthropol Linguist, 1(1), 27-29.

Hashemi, M. R., \& Golparvar, S. E. (2012). Exploring metadiscourse markers in Persian news reports. International Journal of Social Science Tomorrow, 1 .

Hinkel, E. (2005). Hedging, inflating, and persuading in L2 academic writing. Applied Language Learning, 14, $29-54$.

Hyland, K. (1994). Hedging in academic textbooks and EAP. English for Specific Purposes, 13(3), 239-256. https://doi.org/10.1016/0889-4906(94)90004-3

Hyland, K. (1996a). Writing without conviction? Hedging in science research articles. Applied Linguistics, 17(4), 433-454. https://doi.org/10.1093/applin/17.4.433

Hyland, K. (1996b). Talking to the academy: forms of hedging in science research articles. Written Communication, 13(2), 251-281. https://doi.org/10.1177/0741088396013002004

Hyland, K. (1997). Scientific claims and community values: articulating an academic culture. Language and Communication, 16(1), 19-32. https://doi.org/10.1016/S0271-5309(96)00023-7

Hyland, K. (1998). Boosting, hedging and the negotiation of academic knowledge. TEXT, 18(3), 349-382. https://doi.org/10.1515/text.1.1998.18.3.349

Hyland, K. (1998a). Hedging in scientific research articles. Amsterdam: John Benjamins. Hyland, K. (1998b). Persuasion and context: The pragmatics of academic metadiscourse. Journal of Pragmatics, 30, 437-455. https://doi.org/10.1016/S0378-2166(98)00009-5

Hyland, K. (1999). Talking to students: Metadiscourse in introductory course books. English for Specific Purposes, 18(1), 3-26. https://doi.org/10.1016/S0889-4906(97)00025-2

Hyland, K. (2000). Disciplinary discourse: Social interactions in academic writing. London: Longman.

Hyland, K. (2004). Disciplinary interactions: metadiscourse in L2 postgraduate writing. Journal of Second Language Writing, 13, 133-151. https://doi.org/10.1016/j.jslw.2004.02.001

Hyland, K. (2005). Metadiscourse. London: Continuum. https://doi.org/10.1177/1461445605050365

Hyland, K (2005a). Metadiscourse: Exploring interaction in writing. London: Continuum.

Hyland, K. (2005b). Stance and engagement: a model of interaction in academic discourse. Discourse Studies, 7 , 173-192. https://doi.org/10.1177/1461445605050365

Hyland, K. (2007). Applying a gloss: exemplifying and reformulating in academic discourse. Applied Linguistics, 28, 266-285. https://doi.org/10.1093/applin/amm011

Hyland, K. (2017). Metadiscourse: What is it and where is it going? Journal of Pragmatics, 113, 16-29. 
https://doi.org/10.1016/j.pragma.2017.03.007

Hyland, K., \& Milton, J. (1997). Hedging in L1 and L2 student writing. Journal of Second Language Writing, 6(2), 183-206.

Hyland, K., \& Tse, P. (2004). Metadiscourse in academic writing: A reappraisal. Applied Linguistics, 25, 156177. https://doi.org/10.1093/applin/25.2.156

Ifantidou, E. (2005). The semantics and pragmatics of metadiscourse. Journal of Pragmatics, 37, $1325-1353$. https://doi.org/10.1016/j.pragma.2004.11.006

Kopple, W. J. V. (1985). Some exploratory discourse on metadiscourse. College Composition and Communication, 82-93. https://doi.org/10.2307/357609

Le, E. (2004). Active participation within written argumentation: metadiscourse and editorialist's authority. Journal of Pragmatics, 36(4), 687-714. https://doi.org/10.1016/S0378-2166(03)00032-8

Lorés-Sanz, R. (2011). The construction of the author's voice in academic writing: The interplay of cultural and disciplinary factors. Text \& Talk-An Interdisciplinary Journal of Language, Discourse \& Communication Studies, 31(2), 173-193. https://doi.org/10.1515/text.2011.008

Marandi, S. (2002). Contrastive EAP rhetoric: metadiscourse in Persian vs. English. Unpublished doctoral dissertation, University of Tehran, Tehran, Iran.

Mashhady, H., Fatollahi, M., \& Shahraki, A. (2015). A Discourse Analysis Study of English and Persian Newspaper Editorials Based on Halliday’s Functional Grammar. IJLI, 1, 2.

McEnery, T., \& Hardie, A. (2012). Corpus Linguistics: Method, Theory, and Practice. https://doi.org/10.1093/oxfordhb/9780199276349.013.0024

Noorian, M., \& Biria, R. (2017). Interpersonal metadiscourse in persuasive journalism: A study of texts by American and Iranian EFL columnists. Journal of Modern Languages, 20(1), 64-79.

Rezanejad, A., Lari, Z., \& Mosalli, Z. (2015). A cross-cultural analysis of the use of hedging devices in scientific research articles. Journal of Language Teaching and Research, 6(6), $1384-1392$. https://doi.org/10.17507/jltr.0606.29

Salager-Meyer, F. (1994). Hedges and textual communicative function in medical English written discourse. English for Specific Purposes-Elmsford and Oxford, 13, 149-149. https://doi.org/10.1016/0889-4906(94)90013-2

Salager-Meyer, F., Ariza, M. A. A., \& Zambrano, N. (2003). The scimitar, the dagger and the glove: Intercultural differences in the rhetoric of criticism in Spanish, French and English medical discourse (1930-1995). English for Specific Purposes, 22, 223-247. https://doi.org/10.1016/S0889-4906(02)00019-4

Scollon, R., Scollon, S. W., \& Jones, R. H. (2012). What is a discourse approach? Intercultural Communication: A Discourse Approach, 1-25. https://doi.org/10.1002/9781405198431.wbeal0555

Shams, M. R. (2005). Reading English Newspapers. Jungle Publication Tehran.

Sinclair, J. (2004). Planes of discourse. In Trust the Text (pp. 61-76). Routledge.

Tran, T. Q., \& Duong, T. M. (2013). Hedging: A comparative study of research article, results and discussion section in applied linguistics and chemical engineering. English for Specific Purposes World, 41, 1-13.

Valero, G. C. (1996). Contrastive ESP rhetoric: Metatext in Spanish-English economics texts. English for Specific Purposes, 5, 279-294. https://doi.org/10.1016/S0889-4906(96)00013-0

Van Dijk, T. A. (Ed.). (1997). Discourse as social interaction (Vol. 2). Sage.

Vázquez, O. I., \& Giner, D. (2008). Beyond mood and modality: Epistemic modality markers as hedges in research articles. A cross-disciplinary study. https://doi.org/10.14198/raei.2008.21.10

Williams, W. J. (1981). Style: Ten lessons in clarity and grace. Glenview, Illinois: Scott Foresman \& Company.

Yazdani, S., Sharifi, S., \& Elyasi, M. (2014). Exploring hedges and boosters in 9/11 English front page news articles. Asian Journal of Research in Social Sciences and Humanities, 4. https://doi.org/10.4304/tpls.4.2.428-434 


\section{Copyrights}

Copyright for this article is retained by the author, with first publication rights granted to the journal.

This is an open-access article distributed under the terms and conditions of the Creative Commons Attribution license (http://creativecommons.org/licenses/by/4.0/). 